\title{
In vitro testing of titanium knot fastener used in cardiac and general surgery with pull apart force
}

\author{
BM Gersak*, JS Sauer \\ From 23rd World Congress of the World Society of Cardio-Thoracic Surgeons \\ Split, Croatia. 12-15 September 2013
}

\section{Background}

To test 2-0 B. Braun PremiCron Suture Knot Pull Apart Force of Two Suture Lots fastened with Titanuim fastener Cor Knot ${ }^{\circledR}$ and compare them with USP Class I Min. Avg. 2-0 Suture Knot-Pull Tensile Strength (Doubled for Loop Test) - (USP).

\section{Methods}

Two Suture Lots of 2-0 B. Braun PremiCron Suture: Lot \# 1-9364 (24 sutures) and Lot \# 110095 (24 sutures) were used and fastened with titanium fastener Cor Knot $^{\circledR}$. The pull apart force was measured for both of the suture lots.

\section{Results}

The USP Class I Min. Avg. 2-0 Suture Knot-Pull Tensile Strength (Doubled for Loop Test) is defined as $2.88 \mathrm{kgf}$. The Tensile Strength of Lot \# 1-9364 was 4,7761 \pm $0,2005 \mathrm{kgf}$ (mean \pm std dev) - min 4.2282, $\max 5.2289$, and for Lot \# 1-9364 was 5,5151 $\pm 0,2625 \mathrm{kgf}$ (mean \pm std dev) - min 4,0044, max 5,1356, respectively. There were no statistically signiffcant differences between the both lots $(\mathrm{F}$ - test, $\mathrm{p}=0,102)$. Comparing tensile strenght for both lots fastened with Cor Knot ${ }^{\circledR}$ with USP tensile strength, knots fatened with Cor Knot ${ }^{\circledR}$ showed higher tensile strengths for all the 48 knots. The minimall tensile strength was in the lot 2-0 PremiCron P/N M0027845, Lot \# 110095, and was 4,0044 kgf, which is $1 \mathrm{kgf}$ above the recommended USP strength.

\section{Conclusion}

Titanium fastened 2-0 B. Braun PremiCron Sutures of two tested lots showed much higher Knot Pull Apart Force compared with recommended minimal average USP Class I Min. Avg. 2-0 Suture Knot-Pull Tensile

* Correspondence: blaz.gersak@maat.si

LSI SOLUTIONS, 7796 Victor-Mendon Rd., Victor NY 14564, USA
Strength (Doubled for Loop Test). The use of Cor $\mathrm{Knot}^{\mathbb{B}}$ is safe, fast and stong and may be recommended as a routine knot fastener for general and cardiovascular surgery, especially in combination with endoscopic surgery.

Published: 11 September 2013

doi:10.1186/1749-8090-8-S1-P64

Cite this article as: Gersak and Sauer: In vitro testing of titanium knot fastener used in cardiac and general surgery with pull apart force. Journal of Cardiothoracic Surgery 2013 8(Suppl 1):P64.
Submit your next manuscript to BioMed Central and take full advantage of:

- Convenient online submission

- Thorough peer review

- No space constraints or color figure charges

- Immediate publication on acceptance

- Inclusion in PubMed, CAS, Scopus and Google Scholar

- Research which is freely available for redistribution

Submit your manuscript at www.biomedcentral.com/submit

\section{() Biomed Central}

